\title{
Urban Engineering Geological Maps for Bradford, UK
}

\author{
M G Culshaw ${ }^{\mathrm{I}}$ \& K J Northmore ${ }^{2}$
}

\author{
${ }^{1}$ British Geological Survey, Keyworth, Nottingham, NG12 5GG, UK and School of Civil \\ Engineering, University of Birmingham, Edgbaston, Birmingham, B15 2TT, UK \\ (martin.culshaw2@ntlworld.com +44 (0)115 911 9137) \\ ${ }^{2}$ formerly British Geological Survey, Keyworth, Nottingham, NG12 5GG, UK \\ (kevin.northmore@tiscali.co.uk; +44 (0)115923 1638)
}

\begin{abstract}
An applied geological study of the City of Bradford Metropolitan District, UK, was the last of a series of British Government-funded projects to provide background applied geological information for land-use planning and development. This study included a range of engineering geological maps. As well as providing a general engineering geological overview, the maps show foundation conditions, suitability of deposits as engineered fill, excavatability, the thickness of superficial deposits and landslide distribution and slope steepness. The paper briefly describes the content of the maps and how they were produced.
\end{abstract}

Keywords: Engineering geological mapping, Bradford

\section{Introduction}

Between 1980 and 1996, what was originally the UK Government's Department of the Environment (this Department had many name changes during this period) funded a series of applied research projects aimed at developing methods to provide land-use planners in local authorities with relevant geological information to use as part of the planning system of strategic planning and planning control. The final output of the programme was focused on the City of Bradford Metropolitan District of West Yorkshire, in the north of England (UK) (Fig. 1).

The bedrock geology of the area consists of sandstones, mudstones and siltstones of the Carboniferous Westphalian Coal Measures and Namurian Millstone Grit. These rocks are overlain, over much of the area, by glacial and post-glacial superficial deposits and both are overlain, locally, by artificial deposits. By the time that the research was carried out (1993-96), geographical information systems (GIS) had come into common use. Consequently, the maps were produced digitally, though printed versions accompanied the project report.

The research report had two parts: a guide, for land-use planners, to the use of geological information in planning and development and a technical guide for engi- 
neers and geologists to ground conditions (Waters et al. 1996). The planners' guide included a map of geological factors relevant to planning and development. The technical guide included maps of bedrock geology, superficial deposits, mineral resources \& surface mineral workings, mined ground \& shafts, slope steepness \& landslides, engineering ground conditions and water resources and flooding, all at 1:50 000 scale. The engineering ground conditions map was accompanied by additional 1:100 000 scale maps showing foundation conditions, suitability of deposits as engineered fill, excavatability and thickness of superficial deposits.

The report was also accompanied by five digital databases that provided information on: boreholes and trial pits; site investigation reports; landslides; landfill sites; sandstone quarries. Unfortunately, the databases were compiled using the dBase III+ program that was in common use at the time. However, now, these databases would be hard to access and, indeed, may not be accessible at all (Culshaw and Price 2011). The contents of the landslide database have been incorporated into the National Landslide Database (Foster et al. 2012) while the borehole logs were included in the national borehole log database at the British Geological Survey.

This paper describes the content of the engineering geological maps produced as part of the study and how they were developed.

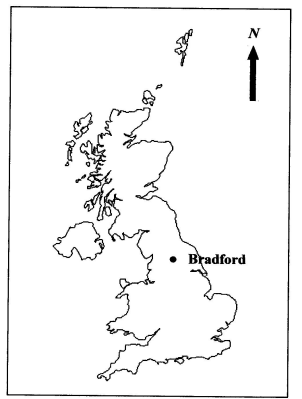

Figure 1. Location of Bradford in the UK (not to scale).

\section{Engineering Geological Maps}

\section{Map of engineering ground conditions of Bedrock and Superficial Deposits}

The general map of engineering ground conditions was reproduced at a medium scale (as defined by Anon. 1976) of 1:50 000. The map and its very large key cannot be reproduced here and are found in Waters et al. (1996). The map shows the distribution of the engineering geological categories of bedrock and superficial de- 
posits and provides a summary of the geotechnical properties. The engineering geological units are shown in Table 1.

\begin{tabular}{|l|l|l|}
\hline \multicolumn{2}{|l|}{ ENGINEERING GEOLOGICAL UNITS } & \multicolumn{2}{l|}{ GEOLOGICAL DEPOSITS } \\
\hline SOILS & Stiff/dense & Till \\
\hline MIXED \\
$\begin{array}{l}\text { COHESIVE/NON- } \\
\text { COHESIVE SOILS }\end{array}$ & Soft/firm & Head \\
\cline { 2 - 3 } & Soft/loose & $\begin{array}{l}\text { Alluvium; Glaciolacustrine De- } \\
\text { posits }\end{array}$ \\
\hline $\begin{array}{l}\text { NON-COHESIVE } \\
\text { SOILS }\end{array}$ & Medium dense \\
\hline ORGANIC SOILS & Very soft & Peat \\
\hline $\begin{array}{l}\text { HIGHLY VARIABLE } \\
\text { DEPOSITS }\end{array}$ & ARTIFICIAL & $\begin{array}{l}\text { Made Ground } \\
\text { Infilled Ground }\end{array}$ \\
\hline $\begin{array}{l}\text { LANDSLIDE DEPOSITS (may include } \\
\text { displaced bedrock) }\end{array}$ & Landslides \\
\hline BEDROCK & \multicolumn{2}{|l|}{} \\
\hline 'STRONG' SANDSTONES & $\begin{array}{l}\text { Sandstones of the Millstone } \\
\text { Grit and Coal Measures }\end{array}$ \\
\hline MUDROCKS & $\begin{array}{l}\text { Mudstones, claystones, shales } \\
\text { and siltstones of the Millstone } \\
\text { Grit and Coal Measures }\end{array}$ \\
\hline
\end{tabular}

Table 1. Engineering geological units

For each of the units shown in Table 1, the key provides information on:

- the stratigraphical units from which the engineering geological units are derived;

- $\quad$ an engineering geological description of the unit;

- a summary of foundation conditions;

- an indication of excavatability;

- a summary of how the unit might be used as engineered fill;

- $\quad$ an outline of what needs to be determined by a ground investigation.

Geological faults at the surface and zones where undermining may occur within $30 \mathrm{~m}$ depth of the ground surface are also shown. Colour-coding of the engineering geological units on the map shows the different stiffnesses/relative densities indicated in Table 1 and whether they are less than, or greater than, $5 \mathrm{~m}$ thick and an inset block diagram shows the $3 \mathrm{D}$ relationships of the units. 


\section{Map of foundation conditions}

The map was based on an interpretation of the lithology, deposit thickness, geotechnical properties and groundwater conditions (as well as local conditions such as the presence of landslides and/or abandoned mineworkings), the map classifies the geological units into five groups:

- rocks that are likely to exhibit good foundation conditions. However, comments are provided with regard to weathering of sandstones and the potential for rapid deterioration of mudrocks when wetted on exposure;

- Superficial deposits, such as glacial tills, glaciofluvial deposits and river terrace deposits that are likely to exhibit good foundation conditions, though the possibility of deep and variable buried channel deposits being present is discussed;

- Superficial deposits, such as alluvium and glaciolacustrine deposits that are likely to be soft and highly compressible and may be liable to severe differential settlement;

- Superficial deposits that are unsuitable as foundations because they are very weak with acidic groundwater (peat) or contain shear surfaces (landslide deposits);

- Artificial ground that may be highly variable and liable to severe total and differential settlement.

Lithological descriptions are given for the materials in each class and recommendations are also provided about what ground investigations should be looking for in relation to foundation conditions.

\section{Map of suitability of deposits as engineered fill}

This map classifies bedrock and superficial deposits in terms of their suitability for use as engineered fill. The geological units have been allocated into the different classes on the basis of a range of properties and characteristics including lithology, weathering, strength and compressibility.

The classification is as follows:

Suitable:

- Rock/granular fill (Sandstones)

- Granular fill (Glaciofluvial Deposits and River Terrace Deposits)

- Cohesive fill (Mudstones and Glacial Till)

Possibly suitable:

- Variable (Alluvium, Glaciolacustrine Deposits, Hummocky Glacial Deposits, Head

Unsuitable:

- Highly variable (Artificial Ground) 
- Organic soil (Peat)

- Landslide deposits

Detailed comments on the different classes are provided in the map key.

\section{Map of excavatability}

This map shows what methods are likely to be appropriate for excavating the various geological units. It produced using the methodology described by Pettifer and Fookes (1994). The strength of the material using the point load index test to determine the unconfined compressive strength and the fracture space index are plotted on a chart from Pettifer and Fookes and whether the material needs blasting, ripping or digging is interpreted. Each of the divisions is sub-divided in the chart.

The map shows three classes of excavation requirements:

- Blasting, pneumatic tools, ripping for sandstones and siltstones of the Millstone Grit and Coal Measures.

- Pneumatic tools, ripping, digging for mudstones and shales of the Millstone Grit and Coal Measures.

- Diggable, for all the Superficial Deposits.

Additional detailed comments are provided for each class, which explain why the first two classes include more than one method for the rock types included.

\section{Thickness of Superficial Deposits map}

This map was created from the borehole and trial pit logs acquired for the project. More than $10000 \operatorname{logs}$ were obtained, though they were not evenly distributed across the Bradford area, being more concentrated in the urban areas and areas underlain by coal and other mineral deposits. Not all the site investigation boreholes and trial pits necessarily reached rockhead and, so, these could not be used to in terpret this map. Borehole logs were obtained from public bodies, local councils and private contractors and consultants.

Five classes for the thickness of natural superficial deposits are shown on the map. (Note: artificial deposits are not included).

- No superficial deposits;

- 1-5 m thickness;

- $5-10 \mathrm{~m}$ thickness;

- $\quad 10-20$ m thickness;

- Greater than $20 \mathrm{~m}$ thickness.

Not surprisingly, the greatest thicknesses of superficial deposits are found along the city's main river, the River Aire, with thicknesses reaching over $20 \mathrm{~m}$. 


\section{Slope steepness and landslides map}

This map shows the distribution of landslide deposits in relation to slope steepness. Five slope steepness classes are included $\left(<3^{0}, 3-7^{0}, 7-11^{0}, 11-15^{0},>15^{0}\right)$. Over 200 landslides were identified, most previously unknown. The majority were relatively shallow, rotational or translational, earth or debris slides in Glacial Till and/or weathered slope mantles. Rotational slides occurred mostly in relatively uniform Till with thicknesses generally $>3.5 \mathrm{~m}$. Translational slides were mainly developed in weathered, more granular debris mantles with planar slip surfaces close to the boundary of less-weathered rockhead. Most of the larger landslides were complex with slide and flow movements. In many cases, the landslides were ancient, degraded and vegetated, sometimes modified by human activity.

\section{Conclusions}

The engineering geological maps of Bradford show that engineering ground conditions vary markedly in response to the material and geotechnical characteristics of the geology, topography, ground and surface waters and past and present human activity. Over most of the area, the ground conditions should pose no major problem to ground engineering, provided that adequate information to properly confirm ground characteristics shown on the maps is obtained for specific sites.

Acknowledgments: This paper is published with the permission of the Executive Director of the British Geological Survey (NERC).

\section{References}

Anon. 1976. Engineering geological maps: a guide to their preparation. Paris: The UNESCO Press.

Culshaw, M. G. and Price, S. J. 2011. The contribution of urban geology to the development, regeneration and conservation of cities. Bulletin of Engineering Geology and the Environment, 70, 333-376.

Foster, C., Pennington, C. V. L., Culshaw, M. G. and Lawrie, K. 2012. The National Landslide Database of Great Britain: development, evolution and applications. Environmental Earth Sciences, 66, 3, 941-953.

Pettifer, G. S. and Fookes, P. G. 1994. A revision of the graphical method for assessing the excavatabilty of rock. Quarterly Journal of Engineering Geology, 27, 145-164.

Waters, C. N., Northmore, K., Prince, G. and Marker, B. R. (eds). 1996. A geological background for planning and development in the City of Bradford Metropolitan district. Technical Report No. WA/96/1. Keyworth, Nottingham: British Geological Survey. 